\title{
Knowledge and preventive practices regarding Hepatitis B among nurses in some selected hospitals of Dhaka city, Bangladesh
}

\author{
Nadira Mehriban ${ }^{1}, G U$ Ahsan $^{2}$, Tajul Islam ${ }^{3}$
}

${ }^{1}$ Assistant Professor, Department of Public Health, Daffodil International University, Dhaka; ${ }^{2}$ Professor and Chairman, Department of Public Health, North South University, Dhaka; ${ }^{3}$ Technical Advisor, JICA, Dhaka, Bangladesh.

\begin{abstract}
Hepatitis B is the most important infectious occupational hazard which the healthcare workers (HCWs) encounter. Healthcare personnel specially nursing staff represents a high risk population for HBV infection. The objective of the study was to assess the level of preventive practices regarding Hepatitis B among nurses and the factors associated with preventive practices. The study was conducted among 300 nurses both from public and private hospitals using a pretested structured questionnaire adopting a purposive sampling technique. The mean age of the respondents was $29.7 \pm 5.8$ and majority of them $(83.7 \%)$ were holding Diploma degrees with $(83.3 \%)$ designated as staff nurse. About $59.7 \%$ were married and $94.3 \%$ were females. One third of the respondents $(34.3 \%)$ were from public institution and $65.7 \%$ from private institution. It was revealed from the study that $(67.3 \%)$ of the respondents had adequate level of knowledge on Hepatitis B but only half of them (49.3\%) had good level of preventive practices. Bivariate analysis showed association between institution, income, age, religion, knowledge and level of preventive practice $(\mathrm{P}<0.05)$. In conclusion it can be said that compared to knowledge of the respondents on Hepatitis B, their preventive practices were low. Appropriate educational and health promotion programs should be implemented to increase the level of preventive practices on Hepatitis B among the nurses.
\end{abstract}

Keywords: Hepatitis B, Knowledge, Preventive practice, Nurse, Bangladesh.

\section{Introduction}

Hepatitis B, an acute inflammatory disease of the liver or a form of viral hepatitis is caused by the hepatitis B virus (HBV). ${ }^{1}$ About 2 billion people worldwide have been infected with the virus and about 350 million live with chronic infection. ${ }^{2}$ An estimated 600,000 persons die each year due to the acute or chronic consequences of hepatitis $\mathrm{B.}^{2}$ Hepatitis B virus is a leading cause of chronic hepatitis, cirrhosis, and hepatocellular carcinoma, accounting for 1 million deaths annually. ${ }^{3}$ Its prevalence approaches $10 \%$ in hyper endemic area, such as Southeast Asia, China, and Africa - more than $8 \%$ of the affected people are chronic carriers of the virus which result either neonatal transmission (vertical) or transmission from one child to another (horizontal). ${ }^{3}$ Among the health care personnel, $\mathrm{HBV}$, and $\mathrm{HCV}$ is transmitted by the skin prick with an infected, contaminated needles and syringes or through accidental inoculation of minute quantities of blood during the surgical and dental procedures. ${ }^{4}$

Health care personnel are at increased risk of contracting blood borne pathogens due to their occupational exposure to blood and body fluids, ${ }^{5}$ More than twenty diseases can get transmitted through needle stick injuries including Hepatitis B, Hepatitis C and HIV. ${ }^{5}$ Global burden of HBV due to contaminated sharp injuries in HCWs is estimated to be 66,000 cases and 261 deaths annually. ${ }^{6}$ In developing countries 40-60\% HBV infections in HCWs are attributed to sharp injuries. ${ }^{6}$ Nurses often have to deal with spilt blood, needle stick and sharps injuries, which

\section{Practice Points}

- Hepatitis B is a major public health problem in most parts of the world.

- Health care personnel are at increased risk of contracting blood borne pathogens due to their occupational exposure to blood and body fluids.

- There is a gap between knowledge and practice of the health care workers.

- It was revealed from the study that $67.3 \%$ of the nurses had adequate level of knowledge on Hepatitis B and $49.3 \%$ had good level of preventive practices.

- The preventive measures which can be taken by health workers to reduce these occupationally related blood borne infections include adhering to universal precautions, immunization against Hepatitis $\mathrm{B}$, provision of personal protective equipment and the management of exposures.

can transmit blood-borne infections between patients and healthcare staff, and infection with the HBV is a common result. ${ }^{7}$ When compared to other health personnel, the nursing staff is the group that is most frequently victimized by accidents with cutting and piercing objects, since these professionals are also the ones who most often handle such material while

Correspondence: Dr. Nadira Mehriban, Assistant Professor, Department of Public Health, Daffodil International University, Dhaka, Bangladesh. Email: nmehriban@yahoo.com. 
performing their tasks. ${ }^{8}$ Occupational accidents, particularly those involving cutting and piercing instruments among health professionals, have been a cause for increasing concern due to the prevalence of diseases and infections caused by the Human Immunodeficiency (HIV), Hepatitis B and Hepatitis C viruses, which are sometimes asymptomatic and unnoticed, thus increasing the possibility of contamination. ${ }^{8}$

Hepatitis B is a vaccine preventable disease for which a safe, immunogenic and effective vaccine is recommended since 1982 though its implementation is still insufficient and a sizable proportion of HCWs never get vaccinated despite potential occupational risk. $^{9}$ The risk of contracting $\mathrm{HBV}$ infection in an unvaccinated person from an $\mathrm{HBV}$-infected needle stick or sharp injury ranges from $6-30 \%{ }^{10}$ Bangladesh belongs to the intermediate prevalence region for HBV infection. Here the lifetime risk of acquiring $\mathrm{HBV}$ is between $20-60 \%$. ${ }^{11}$ Studies from many groups have shown that HBV is responsible for $31.25 \%$ cases of acute hepatitis, ${ }^{12} 76.3 \%$ cases of chronic hepatitis, ${ }^{13}$ $61.15 \%$ cases of cirrhosis of liver, ${ }^{14}$ and $33.3 \%$ cases of hepatocellular carcinoma $(\mathrm{HCC})^{15}$ in Bangladesh. Knowledge of the health care workers plays a key role in prevention of spread of infection. Therefore, the objectives of the present study were to assess knowledge, and practices of nurses regarding hepatitis B.

\section{Materials and Methods}

This cross-sectional study was conducted from AprilJune 2008 at five public and private hospitals in Dhaka city of Bangladesh. The sample was purposively selected. The study population comprised of all the nurses working at these hospitals with at least a diploma degree. A sample of 300 was recruited from all these 5 hospitals.

Data were collected through interview using a pretested structured questionnaire. A knowledge summary score was computed for the 28 questions addressing causes, symptoms transmission, at risk groups and complications of hepatitis B. These scores consisted of the total number of correct answers and therefore the maximum possible score was $28 .{ }^{16}$ Those who answered more than 18 questions correctly were categorized as having adequate knowledge and those who scored less were categorized as having poor knowledge. Similarly a summary score was also computed for assessing level of preventive practice addressing different aspects of preventive practices done by nurses to prevent hepatitis $\mathrm{B}$. There were 10 questions on preventive practices and the maximum possible score was 10. Those who answered 7 questions correctly were categorized as having good preventive practice and those who answered less were categorized as having poor preventive practice.

Data was analyzed using SPSS version 16. Descriptive statistics, Chi square tests and independent sample t-test was used to analyze the data.
Ethical consideration: The research protocol was approved by the Ethics review Committee of North south University. Then informed consent was obtained from each study participants. Moreover confidentiality assured for all the information provided and personal identifiers were not included on questionnaire.

\section{Results}

The mean age of the respondent was $29.7 \pm 5.8$. Majority of them were females $(94.3 \%)$ and $59.7 \%$ were married. More than one third of the respondents $(34.3 \%)$ worked in a public institution. Most of the respondents $(83.7 \%)$ had a diploma in nursing whereas only $(16.3 \%)$ were graduate nurses. More than half $(56.3 \%)$ of them had a family income of more than 10,000 taka per month (Table 1).

\section{Knowledge of Hepatitis $B$}

Knowledge was assessed by questions focusing on sign and symptoms, transmission, treatment and prevention. All the respondents had heard about hepatitis B. Most of the respondents $(92.7 \%)$ could correctly identify the causative organism of hepatitis B. The respondents had knowledge that hepatitis B could be transmitted by unsafe sex (88\%), infected blood transfusion (98\%), needle sharing $(98.7 \%)$, and using same razor or by piercing/tattooing by same object $(86 \%)$ (Table 2$)$. About $(88.3 \%)$ of the respondents said that intravenous

Table 1: Socio-demographic characteristics of respondents $(\mathrm{n}=300)$

\begin{tabular}{|c|c|}
\hline Variables & Respondents (\%) \\
\hline $\begin{array}{l}\text { Institution } \\
\text { Public } \\
\text { Private }\end{array}$ & $\begin{array}{l}103(34.3 \%) \\
197(65.7 \%)\end{array}$ \\
\hline $\begin{array}{l}\text { Gender } \\
\text { Male } \\
\text { Female }\end{array}$ & $\begin{array}{c}17(5.7 \%) \\
283(94.3 \%)\end{array}$ \\
\hline $\begin{array}{c}\text { Education } \\
\text { Diploma } \\
\text { Graduate }\end{array}$ & $\begin{array}{c}251(83.7 \%) \\
49(16.3 \%)\end{array}$ \\
\hline $\begin{array}{l}\text { Designation } \\
\text { Staff nurse } \\
\text { Ward in charge } \\
\text { Supervisor }\end{array}$ & $\begin{array}{c}250(83.3 \%) \\
44(14.7 \%) \\
6(2 \%)\end{array}$ \\
\hline $\begin{array}{l}\text { Family income } \\
\text { Less than Tk } 5000 \\
\text { Tk } 5000-10,000 \\
\text { More than Tk } 10,000\end{array}$ & $\begin{array}{c}29(9.7 \%) \\
102(34 \%) \\
169(56.3 \%)\end{array}$ \\
\hline $\begin{array}{l}\text { Marital status } \\
\text { Married } \\
\text { Unmarried }\end{array}$ & $\begin{array}{l}179(59.7 \%) \\
121(40.3 \%)\end{array}$ \\
\hline $\begin{array}{l}\text { Religion } \\
\text { Muslim } \\
\text { Hindu } \\
\text { Christian } \\
\text { Buddhist }\end{array}$ & $\begin{array}{c}209(69.7 \%) \\
58(19.3 \%) \\
21(7 \%) \\
12(4 \%)\end{array}$ \\
\hline $\begin{array}{l}\text { Age (years) } \\
\text { Mean } \pm \text { SD }\end{array}$ & $29.78 \pm 5.8$ \\
\hline
\end{tabular}

Results were expressed as $\mathrm{n}(\%)$ and mean $\pm \mathrm{SD}$ 
drug user are at risk of acquiring the disease. Out of all $(84.3 \%)$ were aware that health workers are at risk of getting hepatitis B. Majority of the respondents, (79.7\%) said that healthy carrier are capable of spreading the disease. Almost all study participants $(91.7 \%)$ knew that hepatitis B causes hepatocellular cancer/cirrhosis. About $(62.7 \%)$ knew exactly how many doses are required for vaccination. Out of the 300 participants 98 (32.7\%) were within the poor knowledge range whereas 202 $(67.3 \%)$ had adequate knowledge about Hepatitis B and mean knowledge score was 20.62 \pm 3.11 .

Preventive practice of respondents on Hepatitis $B$

Various measures of preventive practices which should to be taken by the nurses include use of gloves, gowns, use of sterilized instrument, blood testing, taking vaccines and use of condoms. Out of 300 respondents, $27 \%$ of the respondents did not use any gloves while handling surgical instruments. Majority of the study participants $(92.7 \%)$ used sterilized instruments. Only (46.3\%) used gowns while handling patients.

It was revealed from the study that $(32 \%)$ practiced sharing of needles. When asked if blood test was done for hepatitis B, (69.3\%) of the respondents agreed they have done the blood test. Regarding vaccination, $59 \%$ of the respondents were vaccinated.

Regarding using of condoms, this question was asked to 179 married respondents and 8 unmarried respondents, who had sexual partners, and out of these 187 respondents $(42 \%)$ said they used condoms during sex and $(20.35 \%)$ said they did not use any condom. (Table $3)$. Out of 300 respondents, only $148(49.3 \%)$ had good preventive practices and $152(50.7 \%)$ had poor preventive practices on Hepatitis $\mathrm{B}$ and mean practice score was $6.06 \pm 1.7$.

Results of categorical bivariate analysis showed that the socio-demographic characteristics, such as income, religion and institution were significantly associated with level of preventive practice $(\mathrm{p}<0.05)$ (Table 4$)$.

Independent sample t-test was done to see association

Table 2: Knowledge on transmission of Hepatitis B $(\mathrm{n}=300)$

\begin{tabular}{|l|c|}
\hline Variables & $\begin{array}{c}\text { Respondents } \\
(\mathbf{\%})\end{array}$ \\
\hline Unsafe sex & $264(88 \%)$ \\
Yes & $36(12 \%)$ \\
No & $294(98 \%)$ \\
\hline Infected blood transfusion & $6(2 \%)$ \\
Yes & \\
No & $296(98.7 \%)$ \\
\hline Needle sharing & $4(1.3 \%)$ \\
Yes & \\
No & $258(86 \%)$ \\
\hline Using same razor Tattoo/Piercing & $42(14 \%)$ \\
Yes & \\
No &
\end{tabular}

Results were expressed as n (\%) between age and level of preventive practice on Hepatitis B. Levene's test was found to be non-significant $(p>0.05)$. So equal variance was assumed (t-6.638) and $p<0.05)$. Thus age was significantly associated with level of preventive practice.

Table 3: Preventive Practices on Hepatitis B $(n=300)$

\begin{tabular}{|c|c|}
\hline Variables & Respondents (\%) \\
\hline $\begin{array}{l}\text { Received vaccine for hepatitis } B \\
\text { Yes } \\
\text { No }\end{array}$ & $\begin{array}{c}177(59 \%) \\
323(41 \%)\end{array}$ \\
\hline $\begin{array}{l}\text { Tested blood for hepatitis } B \\
\text { Yes } \\
\text { No }\end{array}$ & $\begin{array}{r}208(69 . \%) \\
92(30.6 \%)\end{array}$ \\
\hline $\begin{array}{l}\text { Use sterile instruments } \\
\text { Yes } \\
\text { No }\end{array}$ & $\begin{array}{c}278(92.7 \%) \\
22(7.3 \%)\end{array}$ \\
\hline $\begin{array}{l}\text { Use gloves } \\
\text { Yes } \\
\text { No }\end{array}$ & $\begin{array}{c}219(73 \%) \\
81(27)\end{array}$ \\
\hline $\begin{array}{l}\text { Use Gowns } \\
\text { Yes } \\
\text { No }\end{array}$ & $\begin{array}{l}139(46.3 \%) \\
161(53.7 \%)\end{array}$ \\
\hline $\begin{array}{l}\text { Practice sharing of needles } \\
\text { Yes } \\
\text { No }\end{array}$ & $\begin{array}{c}96(32 \%) \\
204(68 \%)\end{array}$ \\
\hline $\begin{array}{l}\text { Practice of recapping } \\
\text { Yes } \\
\text { No }\end{array}$ & $\begin{array}{c}214(4.7 \%) \\
86(95.3 \%)\end{array}$ \\
\hline $\begin{array}{l}\text { Use of Condoms }(n=187) \\
\text { Yes } \\
\text { No }\end{array}$ & $\begin{array}{l}126(42 \%) \\
61(20.35 \%)\end{array}$ \\
\hline
\end{tabular}

Results were expressed as n (\%)

Table 4: Association between socio-demographic factors and preventive practice on Hepatitis $B(n=300)$

\begin{tabular}{|c|c|c|c|}
\hline Variables & $\begin{array}{c}\text { Good } \\
\text { Practice }\end{array}$ & $\begin{array}{c}\text { Poor } \\
\text { Practice }\end{array}$ & $\begin{array}{c}p- \\
\text { value }\end{array}$ \\
\hline \multicolumn{3}{|l|}{ Sex } & \multirow{3}{*}{0.759} \\
\hline Male & 9 & 8 & \\
\hline Female & 139 & 144 & \\
\hline \multicolumn{3}{|l|}{ Education } & \multirow{3}{*}{0.132} \\
\hline Diploma & 119 & 132 & \\
\hline Graduate & 29 & 20 & \\
\hline \multicolumn{3}{|l|}{ Income } & \multirow{4}{*}{0.000} \\
\hline$<\mathrm{Tk} 5000$ & 2 & 27 & \\
\hline Tk5000-10,000 & 32 & 70 & \\
\hline$>$ Tk 10,000 & 114 & 55 & \\
\hline \multicolumn{3}{|l|}{ Marital Status } & \multirow{3}{*}{0.385} \\
\hline Married & 92 & 87 & \\
\hline Unmarried & 56 & 65 & \\
\hline \multicolumn{3}{|l|}{ Religion } & \multirow{5}{*}{0.002} \\
\hline Muslim & 106 & 103 & \\
\hline Hindu & 35 & 23 & \\
\hline Christian & 6 & 15 & \\
\hline Buddhist & 1 & 11 & \\
\hline \multicolumn{3}{|l|}{ Institution } & \multirow{3}{*}{0.000} \\
\hline Public & 93 & 10 & \\
\hline Private & 55 & 142 & \\
\hline
\end{tabular}

South East Asia Journal of Public Health 2014;4(1):48-52 
Table 5: Association between level of knowledge and level of preventive practice

\begin{tabular}{|l|c|c|c|c|}
\hline \multirow{2}{*}{ Level of knowledge } & \multicolumn{3}{|c|}{ Level of preventive practice } & \multirow{2}{*}{$\boldsymbol{p}$-value } \\
\cline { 2 - 4 } & Good & Poor & Total & \\
\cline { 2 - 4 } & No (\%) & No (\%) & $202(67.3 \%)$ & 0.001 \\
\hline Poor knowledge & $124(61.4 \%)$ & $78(38.6 \%)$ & $98(32.7 \%)$ & \\
\hline
\end{tabular}

$\chi^{2}$ test was used. The level of significance at $\alpha=0.05$

Bivariate analysis was also done to assess association between level of knowledge and level of preventive practice (Table 5). The analysis shows that those who have good knowledge among them about 124 (61.4\%) had good preventive practice and $78(38.6 \%)$ had poor preventive practice on Hepatitis B. On the other hand those who had poor knowledge, among them only 24 $(24.5 \%)$ had good preventive practice and 74 (75.5\%) had poor preventive practice on Hepatitis B. It is evident from the result that there is significant association between level of knowledge and level of preventive practice $(p<0.05)$.

\section{Discussion}

Hepatitis B and hepatitis C are major health problems globally casting an enormous burden on the healthcare system and a major source of patient's misery. ${ }^{17,18}$ These are important causes of hepatocellular carcinoma and are likely to remain a serious health problem resulting in substantial morbidity and mortality for several decades to come. ${ }^{19}$ Results of the study showed that majority of the respondents $(92.7 \%)$ were aware of hepatitis B infection which is consistent with a study in Punjab, India. ${ }^{4}$ In this study (98\%) of the respondents replied that hepatitis B spread through blood transfusion which is similar to a study done among nursing students in Nepal. $^{20}$

Regarding preventive measures for hepatitis B (90\%) of respondents of this study viewed avoiding unsafe sex as a preventive measure for hepatitis B infection, (97.7\%) said avoiding needle sharing and (94\%) said screening of blood whereas in the study done among nursing students in Nepal (72.2\%) said avoiding unsafe sex, (93.5\%) avoiding sharing needle and $(80.8 \%)$ screening before blood transfusion as preventive measures, which is dissimilar to this study. The dissimilarity may be because this study included nurses who held either diploma or graduate degrees and had higher knowledge compared to nursing students. In the current study $84.3 \%$ respondents were aware that health workers are at a risk of acquiring hepatitis B which is similar to a study done among medical students in Lahore Medical College, Pakistan. ${ }^{21}$

In our study majority of respondents (93.3\%) said vaccination is an important measure to prevent hepatitis B. A study conducted among dentists in Dhaka also had similar findings. ${ }^{22}$ Despite the recommendations by the WHO for vaccination against hepatitis B infections, only $59 \%$ were found fully vaccinated in our study. It is comparable to a study done among HCW in Islamabad,
Pakistan where vaccination status was $(57.6 \%) .{ }^{6} \mathrm{~A}$ similar study done among health care workers in a tertiary hospital in Multan, Pakistan showed slightly higher figure $(62 \%))^{23}$ However a study in among dentists in Bangladesh showed $75 \%$ vaccinated against hepatitis B which is much higher than this study. ${ }^{22}$

Majority of the respondents of this study demonstrated an adequate level of knowledge of hepatitis B. This finding is however, at variance with another study done in Quetta, Pakistan where the respondents demonstrated a very low knowledge of hepatitis B infection. ${ }^{24}$ The results were similar but slightly better than another study done in Ethopia, ${ }^{16}$ This study showed that there was significant association between level of knowledge and level of preventive practice $(p<0.05)$. The authors concluded that adequate knowledge can lead to good practices. The findings are in line with the results presented by the study in Pakistan ${ }^{24}$ and India. ${ }^{25}$ This cross sectional study was conducted amongst certain group of population i.e. nurses only therefore the study findings cannot be generalized to the other entire healthcare professional in the country.

\section{Conclusion}

It was evident from the study that majority of the respondents had adequate knowledge regarding hepatitis B but their preventive practices are poor. Moreover, all of the respondents were not fully vaccinated against Hepatitis $B$ which made them more vulnerable to the disease in their professional life. Since nurses are at increased risk of acquiring needle stick injury, and exposed to blood and blood products in their clinical practice, they should be vaccinated upon entry into the professional life, Education programs should be focused on increasing nurse's perceived severity to occupational exposure to hepatitis B.

\section{References}

1. Al-Hussami M. Knowledge and acceptance of Hepatitis B vaccine IJHCA 2004;2(1)

2. World Health Organization: Hepatitis B. Fact sheet no: 204> Geneva: WHO, 2011.

3. Malik, A.H. \&Lee, William M. Chronic Hepatitis B Virus Infection: Treatment Strategies for the Next Millennium. Ann Intern Med 2000;132:723-31.

4. Setia S, Gambhir R, Kapoor V, Jindal G, Garg S, Setia S. Attitudes and Awareness Regarding 
Hepatitis B and Hepatitis C Amongst Health care Workers of a Tertiary Hospital in India. Ann Med Health Sci Res 2013; 3:551-8.

5. Holla R, Unnikrishnan B, Ram P, Thapar R, Mithra $\mathrm{P}$, et al. Occupational Exposure to Needle Stick Injuries among Health Care Personnel in a Tertiary Care Hospital: A Cross Sectional Study. J Community Med Health Educ 2014;S2:004.

6. Shagufta H, Niveen AP, Rabia S. Hepatitis B and C Prevalence and Prevention Awareness among Health Care Workers in a Tertiary Care Hospital. IJP 2010;8:16-21.

7. Askarian M, Malekmakan L. The prevalence of needle stick injuries in medical, dental, nursing and midwifery students at the university teaching hospitals of Shiraz, Iran. IJMS 2006;60:227-32

8. Renata KR, Elucir G, Silvia C. Accidents with biological material among undergraduate nursing students in a public Brazilian university. Braz J Infect Dis 2004;8:18-24.

9. CDC. Immunization of Health care workers: Recommendation of advisory committee on Immunization practices (ACIP) and the Hospital infection control practices advisory committee (HICPAC). $M M W R$ 1997;46;1-42.

10. Sharma R, Rasania SK, Verma A. Saudan Study of prevalence and response to needle stick injuries among health care workers in a tertiary care hospital in Delhi, India. IJCM 2010;35:74-7.

11. Salimur R, Mamun M, Karim MF. Guideline for treating hepatitis $\mathrm{B}$ virus infection in Bangladesh. IJH 2009;1:6-12.

12. Mahtab MA, Rahman S, Karim MF.HEV infection as an Aetiologic factor for Acute Hepatitis: Experience from a tertiary hospital in Bangladesh. JHPN 2009;27:14-9.

13. Mahtab MA, Rahman S, Khan M, Kamal M, Karim MF, Ahmed F, et al. Aetiology of chronic hepatitis in Bangladesh. Indian J Gastroenterol 2007;26:142.

14. Afroz S, Mahtab MA, Rahman S, Khan M. Hepatitis B virus is the leading cause of cirrhosis of liver in Bangladesh. Hepatol Int 2007;1:120.

15. Khan M, Zaki KMJ, Ahmed KU, et al. Clinical profile: Prognostic index in hepatocellular carcinoma. Bangladesh Med Res Coun Bull 1991;XVII:49-62.

16. Mesfin YM, Kibret KT. Assessment of Knowledge and Practice towards Hepatitis B among Medical and Health Science Students in Haramaya University, Ethiopia. PLoS One 2013; 8(11):e79642.

17. Pokorski RJ. Cost/benefit of laboratory tests. $J$ Insur Med 2006;38:31-43.

18. Wong JB. Hepatitis C: Cost of illness and considerations for the economic evaluation of antiviral therapies. PharmacoEconomics 2006;24:661-72.

19. Abdul Mujeeb S, Jamal Q, Khanani R, Iqbal N, Kaher S. Prevalence of hepatitis B surface antigen and $\mathrm{HCV}$ antibodies in hepatocellular carcinoma cases in Karachi, Pakistan. Trop Doct 1997;27:45-6.

20. Dillee P, Shree K P, Damaru P. Preventive practices against Hepatitis B: A cross-sectional study among nursing students of Kathmandu. $J$ Sci Soc 2012;39:109-13.

21. Tazeem S, Syed MR, Zain M, Ahmad J. Hepatitis B and C: Knowledge, attitude and Perception of medical students at Lahore Medical \& Dental College, Lahore. PJMHS 2014;8:789-93.

22. Faisal S, Shamim A, Syeda MA, Arup KS, Helal $\mathrm{U}$, Abul KA, et al. Preventive Practice on Hepatitis B Virus Infection among Dentists in Selected Hospitals at Dhaka City, Bangladesh. City Dent. Coll J 2013;10:13-7.

23. Naumn AJ, Muhammad A S, Rehan Y, Ali R, Ijaz H. Hepatitis B vaccination status of health care workers at a tertiary care hospital in Multan. NMJ 2009;1:23-7.

24. Noman H, Mohamed AH, Asrul AS, Fahad S, Maryam F. A cross sectional assessment of knowledge, attitude and practice towards Hepatitis B among healthy population of Quetta, Pakistan. BMC Public Health 2012;12:692.

25. Singh A, Purohit B, Bhambal A, Saxena S, Singh A, Gupta A. Knowledge, Attitudes and Practice regarding infection control measures among dental students in Central India. $J$ Dent Educ 2011;75:421-7. 